\title{
EFEKTIFITAS SOSIALISASI GARAM BERYODIUM TERHADAP PENGGUNAAN GARAM BERYODIUM SECARA MANDIRI DI WILAYAH KERJA PUSKESMAS BATURITI I KABUPATEN TABANAN
}

\author{
Ida Ayu Mirah Rasikawati ${ }^{1}$, Ni Putu Eny Sulistyadewi ${ }^{1}$ \\ Program Studi Ilmu Gizi, Fakultas Ilmu Kesehatan Sains dan Teknologi, Universitas Dhyana Pura \\ Email : idaayumirah71@gmail.com
}

\begin{abstract}
ABSTRAK
Upaya penanggulangan GAKY (Gangguan Akibat Kekurangan Iodium) difokuskan pada peningkatan konsumsi garam beryodium rumah tangga dengan target sebesar yaitu 90\%. Hasil Pemantauan Status Gizi pada tahun 2016-2017 kabupaten Tabanan menduduki peringkat terendah di Propinsi Bali. Cakupan terendah konsumsi garam beryodium rumah tangga adalah di wilayah kerja Puskesmas Baturiti I. Salah satu upaya peningkatan konsumsi garam beryodium adalah dengan memberikan sosialisasi pemanfaatan garam beryodium ke masyarakat guna pengubah perilaku masyarakat menjadi sadar dan mandiri dalam penggunaan garam beryodium. Tujuan dari penelitian ini adalah menganalisa efektifitas sosialisasi garam beryodium terhadap penggunaan garam beryodium secara mandiri di wilayah kerja Puskesmas Baturiti I. Penelitian ini merupakan penelitian kuantitatif jenis diskriptif analitik dengan rancangan penelitian quasi experiment one group pretest posttest design dengan observasi lapangan dan uji cita rasa, jumlah sampel sebanyak 45 orang dari ibu balita dan ibu hamil. Analisis data menggunakan Wilcoxon test dan McNemar test. Hasil analisis data diperoleh bahwa sosialisasi garam beryodium efektif meningkatkan penggunaan garam beryodium secara mandiri dengan menggunakan stimulans garam beryodium, uji garam dan uji cita rasa makanan di wilayah kerja Puskesmas Baturiti I.
\end{abstract}

Kata kunci : sosialisasi, garam beryodium, efektifitas

\begin{abstract}
Efforts to overcome IDD (Iodine-related Disorders) are focused on increasing consumption of household iodized salt with a target of 90\%. The results of monitoring nutritional status in 2016-2017 showed that Tabanan District was ranked lowest in Bali Province. The lowest coverage of consumption of household iodized salt is in the working area of Baturiti Health Center I. One effort to increase the consumption of iodized salt is to provide socialization of the use of iodized salt to the community in order to change the behavior of people to become aware and independent in the use of iodized salt. The purpose of this study is to analyze the effectiveness of iodized salt dissemination on the use of iodized salt independently in the work area of Baturiti Health Center I. This study is a quantitative analytic descriptive study with a quasi-experiment research design of one group pretest posttest design with field observations and taste tests. The total sample of 45 individuals consisted of mothers of infants and pregnant women. Data were analyzed using Wilcoxon test and McNemar test. The of data analysis showes that the dissemination of iodized salt effectively increased the use of iodized salt independently using iodized salt stimulants, salt tests and food taste tests in the working area of Baturiti Health Center I of Tabanan Regency.
\end{abstract}

Keywords: socialization, iodized salt, effectiveness.

\section{PENDAHULUAN}

Upaya penanggulangan GAKY (Gangguan Akibat Kekurangan Iodium) difokuskan pada peningkatan konsumsi garam beryodium dengan tujuan tercapainya Universal Salt Iodization, dengan target rumah tangga mengkonsumsi garam beryodium cukup sebesar 90\% (Minarto,2010).

Gambaran rumah tangga mengkonsumsi garam beryodium di Kabupaten Tabanan menurut hasil Pemantauan Status Gizi pada tahun 2016 sebesar 32,9\% dan pada tahun 2017 sebesar 37,5 \% menduduki peringkat terendah dari sembilan (9) kabupaten di Propinsi Bali. Puskesmas Baturiti I merupakan salah satu dari 20 Puskesmas yang ada di Kabupaten Tabanan. Puskesmas Baturiti I selama 4 tahun terakhir konsumsi garam beryodium di masyarakat rata-rata masih dibawah target nasional $(80 \%)$.

Penelitian Prawini dan Ekawati (2013) tentang gambaran pengetahuan, sikap dan perilaku ibu rumah tangga terhadap garam beryodium menunjukkan adanya pemahaman yang kurang dan sikap negatif terhadap garam beryodium mempengaruhi sebagian besar perilaku ibu rumah 
tangga sehingga tidak mengkonsumsi garam beryodium. Disarankan perlunya dilakukan sosialisasi yang lebih intensif tentang pentingnya garam beryodium dan cara menggunakan garam beryodium untuk meningkatkan pengetahuan dan pemahaman ibu rumah tangga sehingga akhirnya diharapkan mempunyai perilaku yang positif terhadap garam beryodium.

Hasil wawancara peneliti terhadap petugas puskesmas Baturiti I rendahnya cakupan konsumsi garam beryodium di masyarakat karena sebagian besar masyarakat merasakan adanya rasa pahit pada makanan setelah ditambahkan garam beryodium. Penyebaran garam beryodium di wilayah kerja puskesmas Baturiti I cukup memadai bahkan sudah tersedia sampai ke warung-warung yang ada di desa. Sehingga hal ini perlu di sosialisasikan kepada masyarakat tentang manfaat garam beryodium dan dampak GAKY termasuk cara memasak, menyimpan dan menaruh garam beryodium. Sosialisasi ini diharapkan mampu menambah pengetahuan masyarakat, mengubah sikap dan tindakan sehingga menjadi sadar dan mandiri dalam penggunaan garam beryodium.

\section{METODE PENELITIAN}

Penelitian ini merupakan penelitian kuantitatif jenis diskriptif analitik dengan rancangan penelitian quasi experiment one group pretest posttest design. Penelitian dilaksanakan di wilayah kerja Puskesmas Baturiti I Kabupaten Tabanan dengan memilih 1 (satu) desa dari 7 (tujuh) desa dengan cara simple random sampling karena pengambilan dilakukan secara acak tanpa memperhatikan strata yang ada karena dianggap homogen (Sugiyono, 2009). Desa terpilih secara simple random sampling yaitu Desa Apuan dianggap cukup representatif untuk mewakili wilayah kerja Puskesmas Baturiti I. Pengumpulan data dilakukan dengan melakukan pengujian pada 45 orang.

\section{Prosedur Penelitian}

1. Pemilihan sampel

2. Memberikan penjelasan kepada sampel tujuan dilakukan penelitian.

3. Penandatanganan surat persetujuan menjadi sampel

4. Melakukan pengamatan ke rumah sampel

5. Sampel diberikan uji cita rasa makanan yang telah disiapkan.

\section{Uji cita rasa makanan}

Dalam penelitian ini dilakukan uji cita rasa terhadap 2 (dua) jenis makanan yang diolah dengan menambahkan garam beryodium dan tidak beryodium. Dari segi rasa makanan sebagian besar
6. Kegiatan sosialisasi manfaat garam beryodium untuk mencegah GAKY serta melakukan pretes, dan pos test.

7. Melakukan pengamatan ke rumah sampel setelah sosialisasi.

Pengolahan data meliputi uji validitas dan reliabilitas serta pengolahan data kuantitatif. Analisis data untuk membuktikan adanya tidaknya pengaruh dari sosialisasi dilakukan uji Wilcoxon dengan derajat kepercayaan $90 \%(\alpha=0,1)$ dan uji perbedaan McNemar untuk mengetahui ada tidaknya perbedaan sebelum dan sesudah sosialisasi.

\section{HASIL PENELITIAN DAN PEMBAHASAN Karakteristik sampel penelitian}

Tabel 1 menunjukkan data karakteristik sampel menurut umur yaitu sebagian besar sampel berumur 31-40 tahun atau sebesar 48,9\%. Tingkat pendidikan sampel sebagian besar tamat SMA yaitu sebesar $62,2 \%$. Jenis pekerjaan sebagian besar sampel sebagai ibu rumah tangga yaitu sebesar $44,4 \%$.

Tabel 1 Karakteristik Sampel Penelitian

\begin{tabular}{llll}
\hline No. & Karakteristik & Jumlah & $\%$ \\
\hline 1. & Kelompok & & \\
& umur & & \\
& $21-30$ th & 16 & 36,6 \\
$31-40$ th & 22 & 48,9 \\
& $>40$ th & 7 & 15,5 \\
& Total & 45 & 100,0 \\
2. & Tingkat & & \\
Pendidikan & & \\
SD & 5 & 11,1 \\
SMP & 10 & 22,2 \\
SMA & 28 & 62,2 \\
D1/D2/D3 & 2 & 4,4 \\
Total & 45 & 100 \\
Jenis & & \\
Pekerjaan & & \\
Petani & 9 & 20,0 \\
Guru & 1 & 2,2 \\
Karyawan & 12 & 26,7 \\
swasta & 3 & 6,7 \\
Wiraswasta & 20 & 44,4 \\
Ibu rumah & & \\
tangga & & \\
Total & 45 & 100 \\
\hline
\end{tabular}

sampel merasakan enak baik pada makanan AA (80\%) maupun makanan BB $(75,6 \%)$ dengan hasil nilai $\mathrm{p}=0,774(>0,1)$ menunjukkan tidak ada perbedaan rasa makanan antara makanan AA dan BB. Hasil uji cita rasa dapat dilihat pada tabel 2 . 
Tabel 2

Hasil Uji Cita Rasa terhadap Makanan

\begin{tabular}{|c|c|c|c|c|c|c|}
\hline \multirow[t]{2}{*}{ No. } & \multirow[t]{2}{*}{$\begin{array}{l}\text { Variabel } \\
\text { Uji Cita Rasa }\end{array}$} & \multicolumn{2}{|c|}{$\begin{array}{l}\text { Makanan AA } \\
\text { (garam biasa) }\end{array}$} & \multicolumn{2}{|c|}{$\begin{array}{l}\text { Makanan BB } \\
\text { (garam } \\
\text { beryodium) }\end{array}$} & \multirow[t]{2}{*}{ Nilai $\mathrm{p}$} \\
\hline & & $\mathrm{n}$ & $\%$ & $\mathrm{n}$ & $\%$ & \\
\hline \multirow[t]{3}{*}{1.} & $\begin{array}{l}\text { Rasa makanan } \\
\text { a.Enak }\end{array}$ & 36 & 80.0 & 34 & 75.6 & \multirow{3}{*}{0,774} \\
\hline & b.Biasa saja & 9 & 20,0 & 11 & 24,4 & \\
\hline & Jumlah & 45 & 100,0 & 45 & 100 & \\
\hline \multirow[t]{4}{*}{2.} & Rasa pahit & & & & & \multirow{4}{*}{0,754} \\
\hline & a.Ya & 6 & 13,3 & 8 & 17,8 & \\
\hline & b.Tidak & 39 & 86,7 & 37 & 82,2 & \\
\hline & Jumlah & 45 & 100,0 & 45 & 100 & \\
\hline \multirow[t]{4}{*}{3.} & $\begin{array}{l}\text { Makanan yang lebih disukai } \\
\text { oleh responden }\end{array}$ & & & & & \multirow{4}{*}{0,233} \\
\hline & a.Ya & 27 & 60,0 & 18 & 40,0 & \\
\hline & b.Tidak & 18 & 40,0 & 27 & 60,0 & \\
\hline & Jumlah & 27 & 60,0 & 18 & 40,0 & \\
\hline
\end{tabular}

Pada variabel rasa pahit sebagian besar menyatakan makanan tersebut tidak pahit yaitu sebesar 86,7 \% untuk makanan AA dan sebesar 82,2 $\%$ untuk makanan BB dengan nilai $\mathrm{p}=0,754(\mathrm{p}>0,1)$ menunjukkan tidak ada perbedaan rasa pahit pada makanan AA maupun BB.

Hal tersebut menunjukkan bahwa sebenarnya rasa pahit tersebut tidak terasa apabila dalam pemasakan menggunakan garam beryodium dilakukan dengan cara yang benar yaitu ditambahkan pada saat makanan telah matang dan siap disajikan. Cara penambahkan garam beryodium pada makanan sebaiknya sedikit demi sedikit karena takaran garam beryodium jauh lebih sedikit dibandingkan garam biasa yang membutuhkan penambahan lebih banyak untuk mendapatkan rasa yang sesuai dengan yang dinginkan. Dari penelitian ini bisa dikatakan garam beryodium tersebut tidak merubah rasa enak pada makanan, sehingga diharapkan nantinya mampu menghilangkan persepsi masyarakat terhadap adanya rasa pahit pada makanan akibat ditambahkan garam beryodium.

Diantara kedua makanan tersebut makanan yang lebih disukai oleh sampel adalah makanan yang menggunakan garam biasa yaitu sebesar $60 \%$ sedangkan yang menyukai makanan yang mengandung garam beryodium hanya $40 \%$ dengan nilai $\mathrm{p}=0,233(\mathrm{p}>0,1)$ menunjukkan tidak ada perbedaan makanan yang lebih disukai oleh sampel baik makanan AA maupun BB.

\section{Observasi penggunaan garam beryodium}

Cara memeroleh garam sebelum sosialisasi mayoritas membeli sendiri sebesar $97,8 \%$, setelah sosialisasi sebesar $100 \%$, dengan nilai $\mathrm{p}=1,000$ $(\mathrm{p}>0,1)$ menunjukkan tidak ada perbedaan cara mempeoleh garam sebelum dan sesudah sosialisasi.

Lokasi meletakkan garam sebelum sosialisasi sebagian besar dekat dengan kompor yaitu 53,3\%, dan sesudah sosialisasi sebagian besar jauh dari kompor yaitu $62,2 \%$ dengan nilai $p=0,065(p>0,1)$ menunjukkan tidak ada perbedaan lokasi menaruh garam baik sebelum maupun sesudah sosialisasi.

Hasil uji garam sebelum sosialisasi mayoritas tidak berubah menjadi ungu tua $(66,7 \%)$ dan setelah sosialisasi mayoritas berubah menjadi ungu tua yaitu sebesar $66,7 \%$, dengan nilai $p=0,000(p<0,1)$ menunjukkan ada perbedaan hasil uji garam sebelum dan sesudah sosialisasi.

\begin{tabular}{|c|c|c|c|c|c|c|}
\hline \multirow{2}{*}{ No. } & \multirow[b]{2}{*}{ Variabel Pengamatan } & \multicolumn{2}{|c|}{ Sebelum Sosialisasi } & \multicolumn{2}{|c|}{ Setelah Sosialisasi } & \multirow[b]{2}{*}{ Nilai $p$} \\
\hline & & $\mathrm{N}$ & $\%$ & $\mathrm{~N}$ & $\%$ & \\
\hline \multirow[t]{2}{*}{1.} & $\begin{array}{l}\text { Garam yang digunakan } \\
\text { a. Garam beryodium }\end{array}$ & 15 & 33,3 & 30 & 66,7 & \multirow[t]{2}{*}{0,000} \\
\hline & b.Garam biasa & 30 & 66,7 & 15 & 33,3 & \\
\hline \multirow[b]{2}{*}{2.} & $\begin{array}{l}\text { Jumlah : } \\
\text { Bentuk garam }\end{array}$ & 45 & 100 & 45 & 100 & \multirow[b]{2}{*}{0,375} \\
\hline & $\begin{array}{l}\text { a. Halus } \\
\text { b. Krosok } \\
\text { c. Briket }\end{array}$ & $\begin{array}{l}33 \\
12 \\
0\end{array}$ & $\begin{array}{l}73,3 \\
26,7 \\
0,0\end{array}$ & $\begin{array}{l}36 \\
9 \\
0\end{array}$ & $\begin{array}{l}80,0 \\
20,0 \\
0,0\end{array}$ & \\
\hline
\end{tabular}




\begin{tabular}{|c|c|c|c|c|c|c|}
\hline \multirow{5}{*}{3.} & Jumlah : & 45 & 100 & 45 & 100 & \multirow{4}{*}{1,00} \\
\hline & Cara memperoleh garam & & & & & \\
\hline & a. Membeli sendiri & 44 & 97,8 & 45 & 100,0 & \\
\hline & b. Bantuan & 1 & 2,2 & 0 & 0,0 & \\
\hline & Jumlah : & 45 & 100 & 45 & 100 & \multirow{5}{*}{0,06} \\
\hline \multirow{4}{*}{4.} & Lokasi meletakkan garam & & & & & \\
\hline & a.Jauh dari kompor & 21 & 46,7 & 28 & 62,2 & \\
\hline & b.Dekat dengan kompor & 24 & 53,3 & 17 & 37,8 & \\
\hline & Jumlah : & 45 & 100 & 45 & 100 & \\
\hline \multirow{4}{*}{5.} & Kondisi garam & & & & & \multirow{4}{*}{0,250} \\
\hline & a. Kering & 41 & 91,1 & 44 & 97,8 & \\
\hline & b.Lembab & 4 & 8,9 & 1 & 2,2 & \\
\hline & Jumlah : & 45 & 100 & 45 & 100 & \\
\hline \multirow{4}{*}{6.} & Yang memasak di rumah & & & & & \multirow{4}{*}{1,000} \\
\hline & a. Ibu sendiri & 42 & 93,3 & 43 & 95,6 & \\
\hline & b.Asisten & 0 & 0,0 & 0 & 0,0 & \\
\hline & c. Lainnya & 3 & 6,7 & 2 & 4,4 & \\
\hline \multirow{5}{*}{7.} & Jumlah : & 45 & 100 & 45 & 100 & \multirow{5}{*}{0,000} \\
\hline & Hasil uji garam & & & & & \\
\hline & a. Ungu tua & 15 & 33,3 & 30 & 66,7 & \\
\hline & b. Bukan ungu tua & 30 & 66,7 & 15 & 33,3 & \\
\hline & Jumlah : & 45 & 100 & 45 & 100 & \\
\hline
\end{tabular}

Hasil penelitian Yanti, 2014 juga menyatakan bahwa garam yang dikonsumsi masyarakat yaitu garam halus sebesar $68,8 \%$ dari total jumlah $80 \mathrm{Ibu}$ Rumah Tangga yang berada di wilayah kerja puskesmas. Sehingga dapat dikatakan bahwa semakin banyak rumah tangga yang menggunakan garam bentuk halus maka semakin banyak pula rumah tangga yang mendapatkan cukup asupan yodium.

Tingkat kemandirian sampel dalam memilih garam terlihat pada variabel cara memperoleh garam yang digunakan di rumah bahwa pada umumnya sampel membeli garam sendiri tanpa bantuan dari pihak lain maupun bantuan dari desa atau puskesmas, baik membeli garam beryodium maupun garam tidak beryodium. Hasil uji statistik McNemart test dengan nilai $\mathrm{p}=1,000(\mathrm{p}>0,1)$ menunjukkan tidak terdapat perbedaan cara memperoleh garam baik sebelum maupun sesudah sosialisasi. Ini menunjukkan seluruh sampel sudah tergolong mandiri dalam memperoleh garam yang digunakan di rumah baik sebelum maupun sesudah sosialisasi.

Menurut Ali \& Asrori, 2010, perilaku individu dipengaruhi oleh kemampuannya untuk berinteraksi dengan baik dengan lingkungan sosialnya sehingga memiliki tanggung jawab dan lingkungan masyarakat yang aman akan membentuk kepribadian yang mandiri.
Menurut Lembaga Perawatan Psikologi, 2014, mengatakan seseorang yang mandiri biasanya memiliki pengetahuan, menguasai keterampilan dan kemauan yang kuat. Pengetahuan sebagai dasar untuk memahami apa dan mengapa harus dilakukan; dan adanya kemauan yang kuat merupakan daya pacu untuk melakukannya.

Lokasi meletakkan garam sebelum sosialisasi sebagian besar dekat dengan kompor yaitu 53,3\%, dan sesudah sosialisasi sebagian besar jauh dari kompor yaitu $62,2 \%$ dengan nilai $p=0,065(p<0,1)$ menunjukkan ada perbedaan bermakna terhadap lokasi menaruh garam baik sebelum maupun sesudah sosialisasi. Penelitian Bibi Ahmad Chahyanto, 2017 juga menggambarkan garam di tingkat keluarga umumnya diletakkan jauh dari kompor. Garam yang disimpan jauh dari kompor cenderung memiliki kandungan iodium yang cukup, namun tidak terdapat hubungan antara lokasi penyimpanan garam dengan kualitas kadar iodium dalam garam.

\section{Tingkat pengetahuan, sikap dan perilaku sampel terhadap penggunaan garam beryodium}

Tingkat pengetahuan, sikap dan perilaku sampel terhadap penggunaan garam beryodium dapat dilihat pada tabel 4 berikut ini : 
Tabel 4

Frekwensi Pengetahuan, Sikap dan Perilaku Sampel Sebelum dan Sesudah Sosialisasi

\begin{tabular}{lllllll}
\hline \multirow{2}{*}{ No } & Variabel & Sebelum Sosialisasi & \multicolumn{2}{c}{ Sesudah Sosialisasi } & Nilai \\
\cline { 3 - 5 } & n & \% & n & \% & \\
\hline 1. & Pengetahuan & & & & & \\
& a. Baik & 14 & 31.11 & 27 & 60.00 & 0,000 \\
& b. Cukup & 30 & 66.67 & 18 & 40.00 & \\
& c. Kurang & 1 & 2.22 & 0 & 0.00 & \\
\hline & Jumlah & 45 & 100,0 & 45 & 100,0 & \\
\hline 2. & Sikap & & & & & \\
& a. Baik & 25 & 55.56 & 26 & 57.78 & \\
& b. Kurang baik & 20 & 44.44 & 19 & 42.22 & \\
\hline & Jumlah & 45 & 100,0 & 45 & 100,0 & \\
\hline 3. & Perilaku & & & & & \\
& a. Baik & 31 & 68,89 & 31 & 68,89 & \\
& b. Kurang & 14 & 31,11 & 14 & 31,11 & \\
\hline & Jumlah & 45 & 100,0 & 45 & 100,0 & \\
\hline
\end{tabular}

Tabel 4 menunjukkan bahwa tingkat pengetahuan sampel sebelum sosialisasi mayoritas tergolong cukup yaitu sebanyak 66,67 \% dan sesudah sosialisasi mayoritas tergolong baik yaitu sebanyak $60.00 \%$ nilai $\mathrm{p}=0,000(\mathrm{p}<0,1)$ artinya terdapat pengaruh yang signifikan pada pengetahuan sampel sebelum dan sesudah sosialisasi.

Penelitian Sutiah, (2017) juga menyatakan terdapat hubungan antara pengetahuan ibu tentang garam beriodium dengan penggunaan garam beriodium tingkat rumah tangga. Menurut Roza, (2012), peningkatan pengetahuan dan pemahaman pada ibu balita dapat dilakukan dengan menggunakan penyuluhan menggunakan berbagai media. Pengetahuan adalah bagian yang sangat penting bagi terbentuknya perilaku seseorang. Berdasarkan pengalaman dan penelitian perilaku lebih bertahan lama bila didasari oleh pengetahuan daripada perilaku yang tidak didasari oleh pengetahuan (Soekidjo Notoatmodjo, 2003).

Sikap sampel terhadap penggunaan garam beryodium sebelum sosialisasi mayoritas tergolong baik yaitu sebanyak $55,56 \%$ dan sesudah sosialisasi mayoritas tergolong baik yaitu sebanyak $57.78 \%$ dengan nilai $\mathrm{p}=0,001(\mathrm{p}<0,1)$ yang menunjukkan terdapat pengaruh yang signifikan pada sikap sampel sebelum dan sesudah sosialisasi.

Secara umum selisih nilai rata-rata sikap sampel sebelum dan sesudah sosialisasi mengalami peningkatan sebesar 5,34 poin. Hasil uji statistik Wilcoxon test diperoleh nilai $\mathrm{p}$ sebesar 0,001 (p $<0.1$ ), menunjukkan ada pengaruh yang signifikan terhadap sikap sampel sebelum dan sesudah sosialisasi garam beryodium.

Sikap adalah bentuk reaksi seseorang yang belum nampak terhadap suatu stimulus atau objek. Sikap hanya dapat ditafsirkan terlebih dahulu terhadap perilaku yang belum nampak. Sikap secara nyata menunjukkan konotasi adanya kesesuaian reaksi terhadap stimulus tertentu. Sikap berbeda dengan tindakan atau aktivitas, sikap merupakan "pre-disposisi" tindakan atau perilaku (Soekidjo Notoatmodjo, 2003:130).

Perilaku sampel terhadap penggunaan garam beryodium sebelum dan sesudah sosialisasi mayoritas tergolong baik sebanyak $68,89 \%$ dengan nilai $p=0,096(p<0,1)$ artinya terdapat pengaruh yang signifikan terhadap perilaku sampel sebelum dan sesudah sosialisasi.

Sejalan dengan hal tersebut penelitian Sutiah, (2017) terhadap ibu-ibu rumah tangga di Desa Tluwuk Kecamatan Wedarijaksa kabupaten Pati menyatakan bahwa terdapat hubungan antara penyuluhan tenaga kesehatan dengan penggunaan garam beryodium di tingkat rumah tangga. Pemberian penyuluhan kesehatan tentang garam beryodium pada umumnya akan menambah pengetahuan seseorang sehingga seseorang tersebut akan memiliki perilaku yang baik dalam memilih dan menggunakan garam beriodium dalam kehidupan sehari-hari.

Di samping itu adanya faktor yang mendukung mempengaruhi keberhasilan penelitian ini seperti adanya sarana atau media dan teknik yang menarik yang digunakan selama sosialisasi sehingga peserta dapat mendengarkan dan menyimak dengan baik informasi yang diberikan.

Demikian halnya dengan penelitian ini melalui sosialisasi garam beryodium dengan menggunakan stimulans garam beryodium, uji garam dan uji cita rasa makanan mendapatkan hasil bahwa terdapat perbedaan pengetahuan, sikap dan perilaku sampel sebelum dan sesudah sosialisasi. Hal tersebut menunjukkan sosialisasi garam beryodium tersebut cukup efektif terhadap penggunaan garam beryodium di wilayah kerja Puskesmas Baturiti I. 


\section{SIMPULAN} berikut :

Hal-hal yang dapat disimpulkan sebagai

a. Tidak ada perbedaan tingkat kesukaan makanan, cita rasa makanan maupun rasa pahit pada makanan yang diberi garam beryodium maupun tidak diberi garam beryodium.

b. Ada perbedaan garam yang digunakan dan uji garam beryodium rumah tangga sebelum dan sesudah sosialisasi.

c. Ada perbedaan tingkat pengetahuan, sikap dan perilaku sampel terhadap penggunaan garam beryodium secara mandiri sebelum dan sesudah sosialisasi.

d. Sosialisasi garam beryodium efektif meningkatkan penggunaan garam beryodium secara mandiri dengan menggunakan stimulans garam beryodium, uji garam dan uji cita rasa makanan di wilayah kerja Puskesmas Baturiti I.

\section{DAFTAR PUSTAKA}

Ali, M., \& Asrori, M. (2010). Psikologi remaja perkembangan peserta didik. Jakarta: Bumi Aksara.

Bibi Ahmad Chahyanto, dkk, (2010). Penggunaan Garam Beriodium Tingkat Rumah Tangga di Kecamatan Sibolga Utara, Kota Sibolga. Media Litbangkes, Vol. 27 No. 2, Juni 2017, 125-132

Dinas Kesehatan Kabupaten Tabanan, (2017). Profil Kesehatan Kabupaten Tabanan Tahun 2017., Tabanan

Lembaga Perawatan Psikologi, (2014). Membentuk Kemandirian Anak (Remaja). [online]. (diupdate 11 Desember 2014). www.dispsiad.mil.id/.../290-membentukkemandirian-anak-remaja.

Martomijoyo. R. (2016). Faktor-Faktor yang Berhubungan dengan Penggunaan Garam Beriodium pada Rumah Tangga di Desa Jatibarang Baru Kabupaten Indramayu. EJournal Unwir. 7 (3A): 71-77

Notoadmodjo Soekidjo, (2003), Pendidikan dan Prilaku Kesehatan, Asdi Mahasatya, Jakarta.

Notoatmodjo, S., (2003), Ilmu Kesehatan Masyarakat, Jakarta: PT. Rineka Cipta.

Prawini,Gusti Ayu Made., dan Ekawati,Ni Komang, (2013). Gambaran Pengetahuan, Sikap dan prilaku Ibu Rumah Tangga terhadap Garam Beryodium di Desa Lodtunduh Wilayah Kerja UPT Kesehatan Masyarakat Ubud I tahun 2013. Community Health, Volume I No.2 Juli 2013, halaman $122-130$.

Roza, F. (2012). Media Gizi Booklet. Poltekkes Kemenkes RI Padang. Padang.

Sugiyono, (2009). Metode Penelitian Kuantitatif, Kualitatif dan R\&D. Bandung: CV. Alfabeta.

Sutiah, Galuh Nita Prameswari, Oktia Woro Kasmini Handayani, (2017). Faktor yang Berhubungan dengan Penggunaan Garam Beriodium di Tingkat Rumah Tangga. Jurnal of Health Education2 (2) (2017), halaman 179-184.

Yanti, Novi, (2015). Gambaran Perilaku dan Sikap Ibu Rumah Tangga terhadap Konsumsi Garam Beryodium di Wilayah Kerja Puskesmas Toroh I Kabupaten Grobogan Pada Tahun 2014. Skripsi Sarjana Jurusan Ilmu Kesehatan Masyarakat Fakultas Ilmu Keolahragaan. Universitas Negeri Semarang. 